https://doi.org/10.22319/rmcp.v9i3.4490

Nota de investigación

\title{
In vitro ruminal degradation of neutral detergent fiber insoluble protein from tropical pastures fertilized with nitrogen
}

\section{Degradación ruminal in vitro de la proteína insoluble en fibra detergente neutro de pastos tropicales fertilizados con nitrógeno}

Francisco Indalecio Juárez Lagunes ${ }^{\mathrm{a}^{*}}$

Alice N. Pell ${ }^{\mathrm{b}}$

Robert W. Blake

Maribel Montero Lagunes ${ }^{\mathrm{c}}$

Juan Manuel Pinos Rodríguez ${ }^{\mathrm{a}}$

${ }^{a}$ Universidad Veracruzana. Facultad de Medicina Veterinaria y Zootecnia. CP. 91710. Veracruz, Ver. México.

${ }^{\mathrm{b}}$ Cornell University. Animal Science Department. Ithaca, NY. USA.

${ }^{c}$ INIFAP. Campo Experimental La Posta. Medellín, Ver. México.

* Corresponding author: juarezf@hotmail.com

\section{- Abstract:}

The objective was to determine in vitro the NDF insoluble protein (NDIP) extension and degradation rate of four tropical grasses by the potential effect of $\mathrm{N}$ fertilization. The grasses (Andropogon gayanus, Brachiaria brizantha, Cynodon plectostachyus and Megathyrsus maximus) that grow in Mexico were used. Each grass was grown in four plots $(5 \times 5 \mathrm{~m})$, fertilized (relationship equivalent to 0 and $100 \mathrm{~kg} \mathrm{~N} / \mathrm{ha}$ ) and clipped $35 \mathrm{~d}$ after the $\mathrm{N}$ fertilization. A complete randomized block design with factorial arrangement $4 \times 2$, and two replicates per treatment was used, where the factors were grass species and $\mathrm{N}$ fertilization. Non-protein nitrogen (NPN), buffer insoluble protein (IP), NDIP and acid detergent insoluble 
protein (ADIP) were performed. Freeze-dried samples were incubated at 0, 1.5, 3, 6, 9, 12, 24, 48 and $96 \mathrm{~h}$. After fermentation, the CP content of the NDF residues was determined. An exponential equation was used to determine the rate of the NDIP disappearance. There was no detectable interaction between type of grass and fertilization level. The NDIP (as \%CP) averaged $35 \%$ with a range of 10 to $60 \%$. The NDIP variation was primarily due to species. The extent and rates of degradation of the NDIP were $70.6 \%$ and $7.1 \% / \mathrm{h}$ respectively, with no N-fertilization effect. The NDIP was degraded faster $(P \leq 0.05)$ than NDF $(7.7 v s 5.0 \% / \mathrm{h})$. These data show that the NDIP is ruminally degraded and that this fraction significantly contributes to the rumen nitrogen supply.

- Key words: Tropical grasses, Degradation kinetics, Protein fractions, NDF, N fertilization.

\section{- Resumen:}

El objetivo fue determinar la tasa y extensión de degradación ruminal in vitro de la proteína insoluble en fibra detergente neutro (NDIP) de pastos tropicales por efecto de la fertilización nitrogenada. Se analizaron los pastos Andropogon gayanus, Brachiaria brizantha, Cynodon plectostachyus y Megathyrsus maximus. Cada pasto se estableció en cuatro parcelas $(5 \times 5 \mathrm{~m})$, se fertilizó (a una relación equivalente a 0 y $100 \mathrm{~kg}$ N/ha) y se muestreó cada 35 días. El análisis estadístico fue un diseño en bloques completos al azar en un arreglo factorial $4 \times 2$ y dos réplicas por tratamiento. Los factores fueron la especie y la fertilización. Se determinó el nitrógeno no proteico, proteína insoluble en buffer, NDIP y proteína insoluble en fibra detergente ácido (ADIP). Las muestras liofilizadas de los pastos se incubaron por 0, 1.5, 3, 6, 9, 12, 24, 48 y 96 h. Después de la fermentación, se determinó PC en la FDN residual y se calculó la tasa de desaparición de NDIP con una ecuación exponencial. No se detectó efecto de interacción entre especie y fertilización. La NDIP (\%PC) promedió $35 \%$ con rango de 10 a 60 \%. La variación de NDIP fue debido a la especie. La tasa y extensión de la degradación de NDIP fueron del $7.1 \% / \mathrm{h}$ y $70.6 \%$ respectivamente, sin efecto de la fertilización. La tasa de degradación fue más rápida $(P \leq 0.05)$ en la fracción NDIP que en la FDN $(7.7 \%$ vs $5.0 \% / \mathrm{h})$. Los resultados muestran que parte del NDIP es degradado en rumen, pudiendo aportar $\mathrm{N}$ para la actividad microbiana.

- Palabras clave: Pastos tropicales, Cinética de degradación, Fracciones de proteína, FDN, Fertilización nitrogenada.

Recibido 15/05/2017

Aceptado 12/11/2017 
In tropical grasses the fiber-bound protein (neutral detergent insoluble protein, NDIP) accounts for one third of its crude protein content ${ }^{(1,2)}$ which might represent a potential source of protein for ruminal degradation in bovines grazing under tropical conditions. The CNCPS version $6.5^{(3)}$ assumes that the digestion rate of the $\mathrm{PB}_{2}$ fraction (fiber-bound protein) is similar to the $\mathrm{CB}_{3}$ fraction (digestible fiber) and $\mathrm{Higgs}^{(4)}$ validates this assumption assigning, for grass hay, an average digestion rate of $4.5 \% / \mathrm{h}$ for both fractions. Although Ogden ${ }^{(5)}$ showed that in C4-grasses the rate of digestion of the NDIP fraction is faster than its own NDF fraction (11.0 vs $7.8 \% / \mathrm{h})$. In Australian tropical grasses measuring NDIP rates of digestion found a range between 4.7 and $7.9 \% / \mathrm{h}^{(6)}$. However, $\operatorname{Singh}^{(2)}$ for tropical grasses in India consider the Sniffen digestion rate of fiber-bound protein of less than $1.5 \% / \mathrm{h}^{(7)}$. Also, in Brazilian grasses ${ }^{(8)}$ reported digestion rates between 0.08 and $1.3 \% / \mathrm{h}$ for the $\mathrm{PB}_{3}$ fraction. At a given passage rate of $2.5 \% / \mathrm{h} \mathrm{Ogden}^{(5)}$ or a range between $2.0-4.4 \% / \mathrm{h} \mathrm{Bowen}^{(6)}$ it is critical to know if the NDIP digestion rate exceeds or not the passage rate. Because grasses frequently make up the only source of protein for many ruminants, information on the NDIP fraction of grasses is a prerequisite to modeling the $\mathrm{N}$ economy of ruminants.

Concentration, distribution and digestibility of protein in forages is affected by species ${ }^{(9)}, \mathrm{N}$ fertilization ${ }^{(10)}$, and cutting age ${ }^{(8)}$. Data on the effects of these management practices are incomplete. The goals were to examine in vitro the pool size, and extent and rate of digestion of the cell wall protein of four tropical grasses (Andropogon gayanus, Brachiaria brizantha, Cynodon plectostachyus, and Megathyrsus maximus), and to explore the effects of $\mathrm{N}$ fertilization on these variables.

The study was conducted at the experimental station La Posta, of the Instituto Nacional de Investigaciones Forestales, Agrícolas y Pecuarias (INIFAP). Located in the State of Veracruz on the southeastern coast of Mexico at $19^{\circ} 02^{\prime} \mathrm{L}$ and $96^{\circ} 08^{\prime} \mathrm{L}$, at $12 \mathrm{~m}$ asl, tropical subhumid Aw, average annual rainfall of $1,728 \mathrm{~mm}, 25{ }^{\circ} \mathrm{C}$ of average temperature and $81 \%$ relative humidity. The soil is classified as Oxisol, a predominantly sandy loam with $>15 \%$ clay.

The grasses Andropogon gayanus, Brachiaria brizantha, Cynodon plectostachyus, and Megathyrsus maximus Var. Guinea, were selected because they are commonly used in tropical areas. At onset of the rainy season, each grass was grown in four plots $(5 \times 5 \mathrm{~m})$. Two plots were fertilized with $\mathrm{N}$ (relationship equivalent to $100 \mathrm{~kg} \mathrm{~N} / \mathrm{ha}$ ) and other plots not. All plots were previously cut to a height of $5 \mathrm{~cm}$. After $35 \mathrm{~d}$ of regrowth, one sample of $2 \mathrm{~m}^{2}$ from the center of each plot was clipped at a height of $10 \mathrm{~cm}$. A sub-sample of $500 \mathrm{~g}$ of green material was frozen immediately at $-15^{\circ} \mathrm{C}$, and other sub-sample of $500 \mathrm{~g}$ was placed in a forced air oven at $100{ }^{\circ} \mathrm{C}$ during $24 \mathrm{~h}$ for dry matter (DM) determination. This sample was discarded after DM determination. At the end of sampling (July $25^{\text {th }}$ ), four frozen samples 
from each grass were freeze dried, placed in $30 \times 25 \mathrm{~cm}$ heavy duty freezer bags, and sent to Cornell University for laboratory analysis.

All samples were ground through a 1-mm screen in a Wiley mill (Model 4, Arthur H. Thomas Co. Philadelphia, PA). Dry matter was determined by direct oven-drying samples at $100{ }^{\circ} \mathrm{C}$ overnight. Crude protein $(\mathrm{N} \times 6.25)$ was determined by Macrokjeldahl procedure ${ }^{(11)}$, modified by using boric acid at $4 \%$ concentration during distillation. The protein fractions were determined as described by Licitra ${ }^{(12)}$. The $\mathrm{N}$ and protein fractions of the grasses were partitioned according to Pichard and Van Soest ${ }^{(13)}$ and Van Soest ${ }^{(14)}$ as follow: all the nitrogen determinations were converted to protein values by multiplying the amount of $\mathrm{N}$ by 6.25 . The non-precipitable fraction of the Tungstic acid precipitation method was used to measure non protein nitrogen (NPN) which is fraction A, and the borate-phosphate buffer method was employed to measure protein solubility (fraction $\mathrm{B}$ ). The difference between the precipitable fraction in Tungstic acid and soluble in buffer is the true soluble protein (fraction B1 fast solubility). The difference between the insoluble fraction in buffer and soluble in NDF is the B2 fraction (medium solubility). The difference between the insoluble fraction in NDF and soluble in ADF is the B3 fraction (slow solubility). And the protein insoluble in ADF is the $\mathrm{C}$ fraction (indigestible protein).

The bicarbonate-phosphate buffer of Goering and Van Soest ${ }^{(15)}$ was employed in the in vitro medium. An equal amount of cysteine hydrochloride replaced the sodium sulfide. The medium was boiled to remove dissolved gases, cooled, cysteine added $(0.625 \mathrm{mg} / \mathrm{mL})$, and the $\mathrm{pH}$ was adjusted to 6.8 as necessary. Ruminal fluid was collected via ruminal cannula approximately $6 \mathrm{~h}$ after feeding from a $600 \mathrm{~kg}$, mature, non-lactating Holstein cow that was fed ad libitum on average quality mixed hay in order to meet maintenance requirements in accordance with The Institutional Animal Care and Use Committee (IACUC, 2002) protocol.

At the onset of a fermentation, each $120 \mathrm{~mL}$ serum bottle contained $16 \mathrm{~mL}$ medium, $4 \mathrm{~mL}$ ruminal fluid, and $200 \mathrm{mg}$ sample. Incubation times for determining NDIP disappearance were $0,1.5,3,6,9,12,24,48$, and $96 \mathrm{~h}$. At each time point, the gas was released with a needle, the bottle was opened and the fermentation was briefly interrupted by adding $40 \mathrm{~mL}$ of NDF solution. The NDF ${ }^{(16)}$ and NDIP, measured by Kjeldahl analysis of the fiber residue, were determined at each time point. Because of the small size and low nitrogen concentration of the samples, Kjeldahl solutions were diluted by $50 \%$ to increase sensitivity. Reducing agents such as cysteine $\mathrm{HCl}$ and sodium sulfide in the medium may affect the rate of protein degradation ${ }^{(17)}$ especially during the first $2 \mathrm{~h}$ of fermentation (unpublished data). To minimize this effect, blanks containing $200 \mathrm{mg}$ of sample and medium with cysteine $\mathrm{HCl}$ but without rumen fluid were used. The amount of protein in the blanks digested after 
2-h fermentation period was subtracted from the initial amount of protein in the experimental samples.

An exponential equation with lag was used to determine the rate of NDF disappearance ${ }^{(18)}$ : $\mathrm{Y}=\mathrm{a}^{*}\left(\exp \left(-\mathrm{b}^{*}(\mathrm{X}-\mathrm{c})\right)\right)$ where $\mathrm{Y}=$ residual NDF/DM at time $\mathrm{t} ; \mathrm{a}=$ digestible NDF, \%; $\mathrm{b}=$ rate of NDF disappearance, $\% / h$; and $c=l a g$ time, $h$. Because no lag was observed in the NDIP disappearance, an exponential equation without lag was used for NDIP rate computations: $\mathrm{Y}=\mathrm{a}^{*}\left(\exp \left(-\mathrm{b}^{*} \mathrm{X}\right)\right)$ where $\mathrm{Y}=$ residual NDIP/DM at time $\mathrm{t}$; $\mathrm{a}=$ digestible NDIP, $\%$; $\mathrm{b}=$ rate of NDIP disappearance, $\% / \mathrm{h}$.

The goal of this study was to measure the digestion rate of the NDIP, not to determine whether ADIP is digested or not ${ }^{(19)}$. As a result, no ADIP corrections were made. All curves were fitted using Table Curve (version 2.0, Jandel Scientific, San Rafael, CA).

A complete randomized block design with factorial arrangement and two replicates per treatment was used, where the factors were grass species and $\mathrm{N}$ fertilization. A laboratory standard of guinea grass (M. maximus) was used to control for ruminal fluid variation among in vitro runs. A $4 \times 2$ factorial arrangement of forage species (A. gayanus, $B$. brizantha, C. plectostachyus, or M. maximus Var. guinea) and $\mathrm{N}$ fertilization (0 and 100 $\mathrm{kg} / \mathrm{ha}$ ) as factors was used. The grass*fertilizer interaction was used to test for the main effects. The grass*fertilization effects were tested with the rest of the experimental error. Planned comparisons among the forages were estimated using Tukey's W procedure. Results were deemed significant at $P \leq 0.05$ for the grass and for the fertilization effect. The ANOVA analyses were performed using the MINITAB, Version 10 (Minitab Inc., State College, PA). Because there were no interactions (grass $* N$ fertilization) of the $4 \times 2$ factorial arrangement of treatments, means of mean factors (grass or $\mathrm{N}$ fertilization) are shown in separate tables.

Chemical composition, protein fractions, kinetic and potential degradation of tropical grasses are shown in Table 1. The average contents of CP $(8.4 \pm 2.21 \% \mathrm{DM})$ and NDF $(70.0 \pm 3.58 \%$ $\mathrm{DM})$ are within the range of tropical grasses at similar stages of growth ${ }^{(20)}$. Most of the protein is in the buffer insoluble fraction (IP), and the major part of this is in the NDIP. Brachiaria brizantha is an exception because it has low NDIP and ADIP values with corresponding increases in NPN. 
Table 1: Chemical composition, protein fractions, kinetics and neutral detergent insoluble protein (NDIP) potential degradation of tropical grasses

\begin{tabular}{|c|c|c|c|c|c|}
\hline & $\begin{array}{c}\text { Andropogon } \\
\text { gayanus }\end{array}$ & $\begin{array}{c}\text { Cynodon } \\
\text { plectostachyus }\end{array}$ & $\begin{array}{l}\text { Megathyrsus } \\
\text { maximus }\end{array}$ & $\begin{array}{c}\text { Brachiaria } \\
\text { brizantha }\end{array}$ & SEM \\
\hline \multicolumn{6}{|c|}{ Chemical composition (\% DM) } \\
\hline NDF & $71.5^{\mathrm{a}}$ & $74.9^{a}$ & $71.9^{a}$ & $65.3^{b}$ & 0.57 \\
\hline ADF & $41.0^{\mathrm{a}}$ & $41.2^{\mathrm{a}}$ & $42.3^{a}$ & $36.5^{b}$ & 0.18 \\
\hline $\mathrm{CP}(\mathrm{N} \times 6.25)$ & $9.1^{\mathrm{a}}$ & $8.3^{\mathrm{ab}}$ & $7.2^{b}$ & $9.0^{\mathrm{a}}$ & 0.12 \\
\hline NPN $(\mathrm{N} \times 6.25)$ & $1.5^{\mathrm{b}}$ & $1.0^{\mathrm{b}}$ & $1.1^{\mathrm{b}}$ & $2.5^{\mathrm{a}}$ & 0.06 \\
\hline IP $(\mathrm{N} \times 6.25)$ & $7.4^{\mathrm{a}}$ & $5.6^{\mathrm{b}}$ & $5.2^{b}$ & $5.3^{b}$ & 0.11 \\
\hline $\operatorname{NDIP}(\mathrm{N} \times 6.25)$ & $4.4^{\mathrm{a}}$ & $3.1 \mathrm{ab}$ & $2.9^{b}$ & $1.2^{\mathrm{c}}$ & 0.14 \\
\hline ADIP $(\mathrm{N} \times 6.25)$ & $0.6^{\mathrm{b}}$ & $0.8^{a}$ & $0.6^{b}$ & $0.3^{c}$ & 0.02 \\
\hline \multicolumn{6}{|c|}{ Protein fractions (\% CP) } \\
\hline A & $16.6^{b}$ & $12.3^{\mathrm{b}}$ & $16.9^{\mathrm{b}}$ & $29.2^{\mathrm{a}}$ & 0.77 \\
\hline B1 & $2.4^{\mathrm{c}}$ & $19.7^{\mathrm{a}}$ & $10.7^{b}$ & $12.9^{b}$ & 0.68 \\
\hline B2 & $31.7^{c}$ & $29.2^{c}$ & $38.1^{\mathrm{b}}$ & $44.6^{a}$ & 0.86 \\
\hline B3 & $42.5^{\mathrm{a}}$ & $28.1^{\mathrm{b}}$ & $24.9^{b}$ & $9.9 \mathrm{c}$ & 1.06 \\
\hline C & $6.7^{b}$ & $10.6^{\mathrm{a}}$ & $9.4^{\mathrm{a}}$ & $3.5^{\mathrm{c}}$ & 0.28 \\
\hline \multicolumn{6}{|c|}{ NDIP kinetics and potential degradation } \\
\hline Extent, \% & $81.7^{a}$ & $74.1^{\mathrm{b}}$ & $74.5^{b}$ & $52.2^{c}$ & 0.69 \\
\hline Rate, \%/h & $8.4^{\mathrm{a}}$ & $5.2^{b}$ & $9.7^{\mathrm{a}}$ & $5.2^{b}$ & 0.28 \\
\hline Potentially indigestible, \%DM & $0.72^{b}$ & $0.80^{a}$ & $0.67^{b}$ & $0.58^{c}$ & 0.007 \\
\hline Potentially digestible, \%DM & $3.7^{\mathrm{a}}$ & $2.3^{b}$ & $2.2^{b}$ & $0.64^{c}$ & 0.135 \\
\hline Escape, $\% \mathrm{DM}^{* *}$ & $1.3^{\mathrm{a}}$ & $1.1^{\mathrm{a}}$ & $0.75^{b}$ & $0.32^{c}$ & 0.040 \\
\hline Escape, \%NDIP** & $37.9^{b}$ & $48.9^{\mathrm{a}}$ & $34.1^{\mathrm{b}}$ & $49.2^{a}$ & 1.07 \\
\hline Escape, \%potentially digestible ${ }^{* *}$ & $30.8^{a b}$ & $36.2^{\mathrm{a}}$ & $25.3^{b}$ & $25.6^{b}$ & 0.62 \\
\hline
\end{tabular}

When the protein fractions are expressed on a $\mathrm{CP}$ basis, intracellular soluble protein $\left(\mathrm{A}, \mathrm{B}_{1}\right.$, and $\mathrm{B}_{2}$ ) makes up $66 \%$ of the total $\mathrm{CP}$, and the extracellular structural protein $\left(\mathrm{B}_{3}\right.$ and $\mathrm{C}$ ) composes $34 \%$ of the total. The largest pool $(36 \%)$ of the non-cell wall protein is the $\mathrm{B}_{2}$ fraction, which consists of proteins that make up the structure of cellular organelles and some enzymatic complexes ${ }^{(21)}$. The $\mathrm{B}_{3}$ fraction which is the NDIP - ADIP was $26 \%$ of the total $\mathrm{CP}$. Unlike the protoplasmic proteins, the structural proteins are glycoproteins (extensins) with high levels of hydroxyproline ${ }^{(22)}$.

Large variation was found within the protein fractions, primarily due to species. Brachiaria brizantha had a very different protein profile from the others, because it has more $\mathrm{A}$ and $\mathrm{B}_{2}$ and less $\mathrm{B}_{3}$ and $\mathrm{C}$ fractions, suggesting that this forage have a higher percentage of the forage $\mathrm{N}$ in an useable form for ruminants. Andropogon gayanus had about $50 \%$ of its protein in the cell wall. However, $C$. plectostachyus and M. maximus Var. Guinea had similar protein 
profiles. Approximately $10 \%$ of the protein in C. plectostachyus and M. maximus Var. Guinea was ADIP, a fraction often assumed to be unavailable or unused by the animal ${ }^{(19)}$. These variations pose a difficulty when trying to predict protein fractions on grasses with the same $\mathrm{CP}$ content. A situation that arise when NIRS technology is used to predict $\mathrm{N}$ fractions in forages. Even though, total $\mathrm{N}$ is well predicted by NIRS, and NDIP also has an acceptable coefficient of determination (only when there is a strong correlation with total $\mathrm{N}$ ), the protein $\mathrm{B}_{3}$ fraction it is not well predicted given by the accumulation of errors caused by the subtraction process $^{(23)}$. A recommendation is to generate NIRS calibration equations by grass specie.

The extent of digestion at $96 \mathrm{~h}$ ranged from 52.2 to $81.7 \%$ and the rates ranged from 5.2 to $9.7 \% / \mathrm{h}$. These measured rates of NDIP digestion are faster than those in the Cornell Net Carbohydrate and Protein System (CNCPS version 6.5) ${ }^{(4)}$ feed library for the same grasses. The CNCPS is a nutritional model that evaluates the environmental and nutritional resources available in an animal production system and enables the formulation of diets that closely match the predicted animal requirements. Assuming a passage rate of $5 \% / \mathrm{h}$, much of the NDIP will be degraded in the rumen if our rates are used. Data of the present work are in agreement with those found by $\operatorname{Ogden}^{(5)}$. In contrast, when slower rates are used ${ }^{(2,9)}$, the NDIP will make little contribution to the ruminal $\mathrm{N}$ supply. The $\mathrm{B}_{2}$ pool described by Messman ${ }^{(24)}$ was determined mathematically, using a 2-pool model, not by chemical fractionation. Their $\mathrm{B}_{2}$ rates ranged from 0.6 to $1.2 \% / \mathrm{h}$, which are slower than rates of this work, and close to those proposed by Sniffen ${ }^{(7)}$ for the CNCPS version $5.0 \mathrm{~B}_{3}$ fraction.

There is wide variation in NDIP content, and in NDIP extent and rate of digestion due to species. A. gayanus and B. brizantha have similar CP content but their NDIP fraction behave differently. Brachiaria brizantha has less NDIP (15\%CP) and it is only $52.2 \%$ digestible and its digestion rate is slow $(5.2 \% / \mathrm{h})$. On the other hand, half of the $\mathrm{CP}$ in A. gayanus is NDIP, but this NDIP is $81.7 \%$ digestible with a digestion rate of $8.4 \% / \mathrm{h}$. C. plectostachyus and $M$. maximus Var. Guinea contain the same amount of NDIP, but their rate constants were different (5.2 vs $9.7 \% / \mathrm{h}$ ). Therefore, at a given passage rate, more of the NDIP from $M$. maximus would be ruminally available despite the fact that it had the same NDIP content as C. plectostachyus.

The species variation in the rate of digestion of the NDIP may be due to differences in the extent of glycosylation and amino acid profile of the structural proteins ${ }^{(22)}$. The role of moderately glycosylated extensin proteins; hyperglycosylated arabinogalactan proteins ${ }^{(25)}$; and hidroxiprolin/proline-rich proteins that may be no glycosylated at all as important components of cell wall proteins, play pivotal roles in cell wall signal and affects the amount of intra and intermolecular cross-linking ${ }^{(26)}$. Both glycosylation and cross-linking may affect ruminal degradation.

The first step in predicting the amount of undegradable protein in the NDIP was to evaluate how much remained undegraded after $96 \mathrm{~h}$ of in vitro fermentation. Between $16 \%$ (A. 
gayanus) and $50 \%$ (B. brizantha) of the NDIP remained after $96 \mathrm{~h}$. Following the calculations of Anderson $^{(27)}$ and using a fixed passage rate of $5 \% / \mathrm{h}$, the NDIP escaping ruminal digestion ranged from 0.32 to $1.32 \%$ of DM. Bowen ${ }^{(6)}$ found a range from 0.50 to $1.0 \%$ of DM of rumen undegradable protein fraction actually measuring passage rate in $\mathrm{C} 4$ grasses. The escape value was highest for A. gayanus and lowest for B. brizantha. Expressing this fraction as a percentage of the NDIP indicates that between 25.3 to $36.2 \%$ escaped the rumen and was available for digestion in the intestine.

The residual NDIP of $B$. brizantha after $96 \mathrm{~h}$ of fermentation was double the ADIP level. This implies that part of the NDIP would not be digested in the rumen even with long retention times. This observation may lead us to question the use of ADIP as an indicator of indigestible $\mathrm{N}$ in the rumen. Microbial contamination was not an interference due to its removal by either NDF or ADF solutions.

Means by effect of $\mathrm{N}$ fertilization on chemical composition, protein fractions, kinetics and potential degradation of tropical grasses are shown in Table 2. Nitrogen fertilization increased $(P \leq 0.05) \mathrm{N}$ content as has been reported in different studies ${ }^{(28,29)}$. Mass protein fractions (\%DM): NPN, IP, NDIP and ADIP tended to follow the total protein mass fraction. Similar response in Lolium perenne found Hoekstra ${ }^{(30)}$.

Table 2: Effect of $\mathrm{N}$ fertilization on average chemical composition, protein fractions, kinetics and NDIP potential degradation of tropical grasses

\begin{tabular}{|c|c|c|c|}
\hline & \multicolumn{2}{|c|}{$\mathrm{N}$ fertilization $\mathrm{kg} / \mathrm{ha}$} & \multirow[b]{2}{*}{ SEM } \\
\hline & 0 & 100 & \\
\hline \multicolumn{4}{|c|}{ Chemical composition (\% DM) } \\
\hline NDF & 72.1 & 69.7 & 0.29 \\
\hline ADF & 40.3 & 40.2 & 0.09 \\
\hline $\mathrm{CP}(\mathrm{N} \times 6.25)$ & $5.9^{b}$ & $10.9^{a}$ & 0.06 \\
\hline NPN $(\mathrm{N} \times 6.25)$ & $1.2^{b}$ & $1.8^{\mathrm{a}}$ & 0.03 \\
\hline $\mathrm{IP}(\mathrm{N} \times 6.25)$ & $4.1^{\mathrm{b}}$ & $7.6^{\mathrm{a}}$ & 0.06 \\
\hline $\operatorname{NDIP}(\mathrm{N} \times 6.25)$ & $2.2^{b}$ & $3.6^{\mathrm{a}}$ & 0.07 \\
\hline $\operatorname{ADIP}(\mathrm{N} \times 6.25)$ & $0.5^{\mathrm{b}}$ & $0.7^{a}$ & 0.01 \\
\hline \multicolumn{4}{|c|}{ Protein fractions (\% CP) } \\
\hline A & 20.8 & 16.7 & 0.38 \\
\hline B1 & 9.3 & 13.5 & 0.34 \\
\hline B2 & $33.4^{b}$ & $38.4^{a}$ & 0.43 \\
\hline B3 & 27.6 & 25.1 & 0.53 \\
\hline C & 8.8 & 6.3 & \\
\hline \multicolumn{4}{|c|}{ NDIP kinetics and potential degradation } \\
\hline Extent, \% & 65.7 & 75.5 & 0.34 \\
\hline Rate, $\% / h$ & 6.7 & 7.6 & 0.14 \\
\hline
\end{tabular}


The impact of $\mathrm{N}$ fertilization on the distribution of the protein fractions results in more true cellular protein $\left(\mathrm{B}_{2}\right)$. Similar response found Johnson ${ }^{(10)}$ fertilizing $C$. dactylon in Florida at different rates of $\mathrm{N}$, concluding that the nitrogen pool available for rumen microbes to be utilized in microbial protein synthesis is increased in tropical forages as fertilization rates increase. In contrast, with temperate grasses Hoekstra ${ }^{(30)}$ using L. perenne did not found any effect at all of the nitrogen fertilization on the nitrogen fractions suggesting that appears to be limited scope for the manipulation of grass-protein fractionation through grass fertilization. Because $\mathrm{N}$-fertilized grasses had more $\mathrm{N}$ in the more digestible fractions, more $\mathrm{N}$ retention would be expected. The digestion rates for NDIP were not affected by $\mathrm{N}$ fertilization. In the literature review, it was not find evidence of $\mathrm{N}$ fertilization on digestion rate of the NDIP fraction in tropical forages.

Results for extent and rate of degradation of the NDF are presented in Figure 1. The range in the rates of the NDF disappearance is in agreement with those found elsewhere ${ }^{(31)}$ in some tropical forages $(5-6 \% / \mathrm{h})$, and with those suggested by the CNCPS ${ }^{(4)}$ for grass hay $(4.5 \pm$ $1.0 \% / \mathrm{h})$. The digestion coefficients for NDF were lower than those for the NDIP $(P \leq 0.05)$. Also, Ogden ${ }^{(5,32)}$ shows that rates of digestion of NDIP fraction are faster than the NDF fraction and also found that the effective disappearance of NDIP is considerably higher than for NDF. Lignin (the major determinant of indigestibility) ${ }^{(14)}$ does not seem to affect the structural proteins the same way as it inhibits digestion of structural carbohydrates. For instance, glycoproteins may be more readily digested than cellulose or hemicellulose because there are no linkages between lignin and extracellular proteins. Besides, proline the most extensive amino acid in structural proteins ${ }^{(26)}$, is extremely soluble as $14 \mathrm{~kg}$ of it can be dissolved in $1 \mathrm{~kg}$ of water $^{(33)}$. Weiss ${ }^{(34)}$ could not find evidence that lignin interferes directly with CP digestion.

Figure 1: Comparison of extent and rate degradation of neutral detergent fiber (NDF) versus neutral detergent insoluble protein (NDIP) in tropical grasses
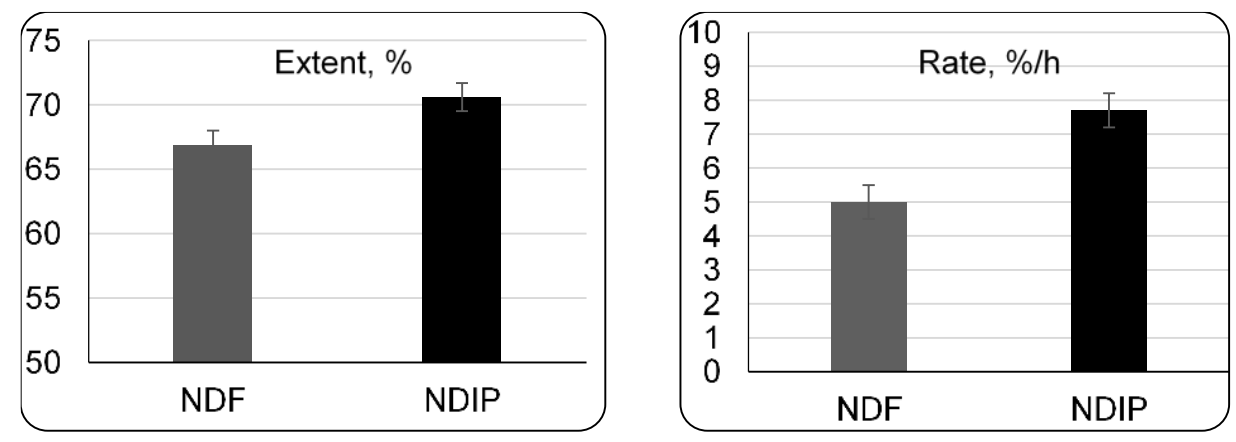
The NDIP as a percentage of the CP averaged 35 with a range of 10 to 60 . The NDIP variation was primarily due to species but fertilization also was a factor. The NDIP is potentially ruminally available with an extent of $70.6 \%$ at a rate of $7.1 \% / \mathrm{h}$. Nitrogen fertilization had no influence on the kinetics of the NDIP digestion. The NDIP was digested faster than the NDF.

\section{Acknowledgements V}

This work was funded by Cornell University Animal Science Department. We thank professors Peter Schofield, Dany G. Fox, Jimmy B. Robertson and Peter J. Van Soest for their guidance during this research.

\section{- Literature cited}

1. Juarez-Lagunes FI, Fox DG, Blake RW, Pell AN. Evaluation of tropical grasses for milk production by dual-purpose cows in tropical Mexico. J Dairy Sci 1999;(82):2136-2145.

2. Singh S, Anele UY, Edmunds B, Südekum K-H. In vitro ruminal dry matter degradability, microbial efficiency, short chain fatty acids, carbohydrate and protein fractionation of tropical grass-multipurpose tree species diets. Liv Sci 2014;(160):4551.

3. Van Amburgh ME, Collao-Saenz EA, Higgs RJ, Ross DA, Recktenwald EB, Raffrenato E, et al. The Cornell Net Carbohydrate and Protein System: Updates to the model and evaluation of version 6.5. J Dairy Sci 2015;(98):6361-6380.

4. Higgs RJ, Chase L.E, Ross DA, Van Amburgh ME. Updating the Cornell Net Carbohydrate and Protein System feed library and analyzing model sensitivity to feed inputs. J Dairy Sci 2015;(98):6340-6360.

5. Ogden RK, Coblentz WK, Coffey KP, Turner JE, Scarbrough DA, Jennings JA, Richardson MD. Ruminal in situ disappearance kinetics of nitrogen and neutral detergent insoluble nitrogen from common crabgrass forages sampled on seven dates in northern Arkansas. J Anim Sci 2006;(84):669-677. 
6. Bowen NK, Poppi DP, McLennan SR. Ruminal protein degradability of a range of tropical pastures. Aust J Exp Agric 2008;(48):806-810.

7. Sniffen CJ, O'Connor JD, Van Soest PJ, Fox DG, Russell JB. A net carbohydrate and protein system for evaluating cattle diets: II. Carbohydrate and protein availability. J Anim Sci 1992;(70):3562-3577.

8. Campos, PR de SS, da Silva JFC, Vásquez HM, Vittori A, Almeida e Silva M. Fractions of carbohydrates and of nitrogenous compounds of tropical grasses at different cutting ages. R Bras Zootec 2010;39(7):1538-1547.

9. Singh S, Kushwaha BP, Nag SK, Mishra AK, Singh A, Anele UY. In vitro ruminal fermentation, protein and carbohydrate fractionation, methane production and prediction of twelve commonly used Indian green forages. Anim Feed Sci Technol 2012;(178):211.

10. Johnson CR, Reiling BA, Mislevy P, Hall MB. Effects of nitrogen fertilization and harvest date on yield, digestibility, fiber, and protein fractions of tropical grasses. J Anim Sci 2001;(79):2439-2448.

11. AOAC Official methods of analysis. $15^{\text {th }}$ ed. Arlington, VA, USA: Association of Official Analytical Chemists. 1990.

12. Licitra G, Hernandez TM, Van Soest PJ. Standardization of procedures for nitrogen fractionation of ruminant feeds. Anim Feed Sci Technol 1996;(57):347-358.

13. Pichard G, Van Soest PJ. Protein solubility of ruminant feeds. Proc Cornell Nutrition Conf Feed Manufacturers. Ithaca, New York, USA, 1977:91-98.

14. Van Soest PJ. Nutritional ecology of the ruminant. Ithaca, New York, USA: Cornell University Press; 1994.

15. Goering HK, Van Soest PJ. Forage fiber analysis (apparatus, reagents, procedures, and some applications). Washington, DC, USA: Agric. Handbook No. 379. ARS-USDA; 1970.

16. Pell AN, Schofield P. Computerized monitoring of gas production to measure forage digestion in vitro. J Dairy Sci 1993;(76):1063-1073.

17. Kohn RA. In vitro methods to determine protein degradation of feeds for ruminants [doctoral thesis]. East Lansing, Michigan, USA: Michigan State University; 1993.

18. Mertens DR, Loften JR. The effect of starch on forage fiber digestion kinetics in vitro. J Dairy Sci 1980;(63):1437-1446. 
19. Van Soest PJ, Mason VC. The influence of the Maillard reaction upon the nutritive value of fibrous feeds. Anim Feed Sci Technol 1991;(32):45-53.

20. Pal K, Patra AK, Sahoo A. Evaluation of feeds from tropical origin for in vitro methane production potential and rumen fermentation in vitro. Span $\mathrm{J}$ Agric Res 2015;13(3):e0608.

21. Salisbury FB, Ross CW. Plant physiology. Belmont, California, USA. Wadsworth Publishing Co.; 1992.

22. Brett C, Waldron K. Physiology and biochemistry of plant cell walls. London, UK: Chapman and Hall; 1996.

23. Valdes C, Andres S, Giraldez FJ, Garcia R, Calleja A. Potential use of visible and near infrared reflectance spectroscopy for the estimation of nitrogen fractions in forages harvested from permanent meadows. J Sci Food Agric 2006;(86):308-314.

24. Messman MA, Weiss WP, Erickson DO. Effects of nitrogen fertilization and maturity of bromegrass on nitrogen and amino acid utilization by cows. J Anim Sci 1992;(70):566-575.

25. Lamport DTA, Kieliszewski MJ, Chen Y, Cannon MC. Role of the extensin superfamily in primary cell wall architecture. Plant Physiol 2011;(156):11-19.

26. Kishor PBK, Hima Kumari P, Sunita MSL, Sreenivasulu N. Role of proline in cell wall synthesis and plant development and its implications in plant ontogeny. Frontiers Plant Sci 2015;6:1-17. doi: 10.3389/fpls.2015.00544.

27. Anderson SJ, Klopfenstein TJ, Wilkerson VA. Escape protein supplementation of yearling steers grazing smooth brome pastures. J Anim Sci 1988;(66):237-242.

28. Castagnara DD, Mesquita EE, Neres MA, Oliveira PSR, Deminicis BB, Bamberg R. Nutritional value and structural characteristics of tropical grasses under nitrogen fertilization. Arch Zootec 2011;60(232):931-942.

29. Boschma SP, Murphy SR, Harden S. Herbage production and persistence of two tropical perennial grasses and forage sorghum under different nitrogen fertilization and defoliation regimes in a summer-dominant rainfall environment, Australia. Grass Forage Sci 2015;70(3):381-393.

30. Hoekstra NJ, Struik PC, Lantinga EA, Van Amburgh ME, Schulte RPO. Can herbage nitrogen fractionation in Lolium perenne be improved by herbage management? NJAS Wagen J Life Sci 2008;55(2):167-180. 
31. Mertens DR. Application of theoretical mathematical models to cell wall digestion and forage intake in ruminants [doctoral thesis]. Ithaca, New York, USA: Cornell University; 1973.

32. Ogden RK, Coblentz WK, Coffey KP, Turner JE, Scarbrough DA, Jennings JA, Richardson MD. Ruminal in situ disappearance kinetics of dry matter and fiber in growing steers for common crabgrass forages sampled on seven dates in northern Arkansas. J Anim Sci 2005;(83):1142-1152.

33. LeRudulier D, Strom AR, Dandekar AM, Smith LT, Valentaine RC. Molecular biology of osmoregulation. Science 1984;(224):1064-1068.

34. Weiss WP, Conrad HR, St. Pierre NR. A theoretically-based model for predicting total digestible nutrient values of forages and concentrates. Anim Feed Sci Technol 1992;(39):95-110. 